\title{
STUDY OF VARIATION OF THE DIAMETER OF THE SPINAL CANAL AND THE FORAMINA IN SPONDYLOLISTHESIS
}

\author{
ESTUDO DA VARIAÇÃO DO DIÂMETRO DO CANAL E DOS \\ FORAMES VERTEBRAIS NA ESPONDILOLISTESE \\ ESTUDIO DE LA VARIACIÓN DEL DIÁMETRO DEL CANAL Y DE \\ LOS FORÁMENES VERTEBRALES EN ESPONDILOLISTESIS
}

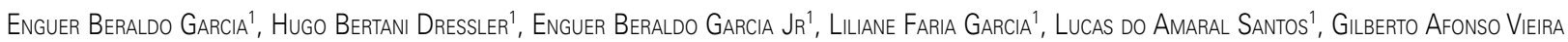
Barros ${ }^{1}$, Roberto Garcia Gonçalves ${ }^{1}$, José Carlos Tadeu Martins², Rogéria Nobre Rodrigues²

1. Santa Casa de Belo Horizonte, MG, Brasil.

2. Axial Centro de Imagens Diagnósticos S.A, Belo Horizonte, MG, Brasil.

\begin{abstract}
Objective: To define and quantify the degree of change of the spinal canal diameter in patients with degenerative and spondylolytic spondylolisthesis. Methods: We studied CT scans of 54 patients. Of this total, 37 (29 women and 8 men) had degenerative type and 17 (7 women and 10 men) had spondylolytic type. Results: In the degenerative spondylolisthesis group, the average diameter of the spinal canal at the injured vertebra level was $17.35 \mathrm{~mm}$ and $17.64 \mathrm{~mm}$ for the upper vertebra level. The average diameter of the foramen at the level of the affected vertebra was $14.61 \mathrm{~mm}$ to left side and $15.00 \mathrm{~mm}$ to the right side. The average diameter of the foramen at the upper vertebra level was $16.82 \mathrm{~mm}$ to the left side and $16.51 \mathrm{~mm}$ to the right side. In the spondylolytic group, the average diameter of the spinal canal at the level of the affected vertebra was $23.25 \mathrm{~mm}$ and at the upper vertebra level was 18.66 $\mathrm{mm}$. The average diameter of the foramen at the level of the affected vertebra was $11.98 \mathrm{~mm}$ to the left side and $12.34 \mathrm{~mm}$ to the right side. The average diameter of the foramen at the level of the upper vertebra was $16.97 \mathrm{~mm}$ to the left side and $15.58 \mathrm{~mm}$ to the right side. Conclusion: The diameter of the spinal canal in the sagittal plane showed no statistically significant increase in the spondylolytic spondylolisthesis group, in contrast to what is found in the degenerative spondylolisthesis group. It was also observed a reduction in vertebral foramina of the injured level in both groups.
\end{abstract}

Keywords: Spondylolisthesis; Spinal stenosis; Spinal canal.

\section{RESUMO}

Objetivo: Definir e quantificar o grau de alteração do diâmetro do canal vertebral em pacientes portadores de espondilolistese degenerativa e espondilolítica. Métodos: Tomografias de 54 pacientes foram estudadas. Desse total, 37 (29 mulheres e 8 homens) apresentavam o tipo degenerativo e 17 (7 mulheres e 10 homens) apresentaram o tipo espondilolítico. Resultados: No grupo de espondilolistese degenerativa, o diâmetro médio do canal no nível da vértebra lesada foi 17,35 mm e 17,64 mm no nível da vértebra superior. O diâmetro médio do forame no nível da vértebra lesada foi 14,61 mm à esquerda e 15,00 mm à direita. O diâmetro médio do forame no nível da vértebra superior foi $16,82 \mathrm{~mm}$ à esquerda e 16,51 mm à direita. No grupo espondilolítico, o diâmetro médio do canal no nível da vértebra lesada foi 23,25 mm e no nível da vértebra superior foi 18,66 mm. O diâmetro médio do forame no nível da vértebra lesada foi 11,98 mm à esquerda e 12,34 mm à direita. O diâmetro médio do forame no nível da vértebra superior foi 16,97 mm à esquerda e 15,58 mm à direita. Conclusão: 0 diâmetro do canal vertebral no plano sagital não apresentou aumento estatisticamente significante no grupo espondilolistese espondilolítica, ao contrário do que se observou no grupo espondilolistese degenerativa. Observou-se também a redução dos forames no nível da vértebra lesada em ambos os grupos.

Descritores: Espondilolistese; Estenose espinal; Canal vertebral.

\section{RESUMEN}

Objetivo: Definir y cuantificar el grado de cambio del diámetro del canal espinal en pacientes con espondilolistesis degenerativa y espondilolítica. Métodos: Hemos estudiado las TC de 54 pacientes. De este total 37 (29 mujeres y 8 hombres) tenían el tipo degenerativo y 17 (7 mujeres y 10 hombres) tenían el tipo espondilolítico. Resultados: En el grupo espondilolistesis degenerativa, el diámetro medio del canal en el nivel de la vértebra lesionada fue 17,35 mm y 17,64 mm para el nivel de la vértebra superior. El diámetro medio del foramen en el nivel de la vértebra lesionada fue $14,61 \mathrm{~mm}$ a la izquierda y $15,00 \mathrm{~mm}$ a la derecha. El diámetro medio del foramen en el nivel de la vértebra superior fue 16,82 $\mathrm{mm}$ a la izquierda y 16,51 $\mathrm{mm}$ a la derecha. En el grupo espondilolítico, el diámetro medio del canal en el nivel de la vértebra lesionada fue 23,25 mm y en el nivel de la vértebra superior fue 18,66 mm. El diámetro medio del foramen en el nivel de la vértebra lesionada fue 11,98 mm a la izquierda y 12,34 mm a la derecha. El diámetro medio del foramen en el nivel de la vértebra superior fue 16,97 mm a la izquierda y 15,58 mm a la derecha. Conclusión: El diámetro del canal vertebral en el plano sagital no mostró ningún aumento estadísticamente significativo en el grupo espondilolistesis espondilolítica, contrariamente a lo que se observó en el grupo espondilolistesis degenerativa. También se observó reducción en los forámenes vertebrales en el nivel lesionado en ambos grupos.

Descriptores: Espondilolistesis; Estenosis espinal; Canal Vertebral. 


\section{INTRODUCTION}

Anterior or posterior slippage of one spinal segment to the detriment of an adjacent segment is called spondylolisthesis. Herbineaux, a Belgian obstetrician, is credited with the first description of spondylolisthesis when, in 1782, he noted a bony prominence in front of the sacrum that caused problems in delivery. The term was used by Kilian in 1854 and is derived from the Greek spondylos (vertebra), olisthesis (slippage), and schisis (breakage). ${ }^{1,2}$

The incidence of spondylolisthesis and its predominance by sex both vary by age group. The etiology is debated, with numerous theories having been proposed, among which trauma and dysplasia stand out. It has great clinical significance for its prevalence as one of the main causes of lower back pain in adolescents.

It can be accompanied by a fracture of the pars articularis and appears to result from a stress fracture, which occurs in children with a genetic predisposition for the disease, given that the defect was not noticed at birth, or in chronically bedridden patients. In a classic study published in 1976, a widely used classification system based on etiology and comprised of five types was established. ${ }^{3}$ The degenerative and isthmic types are the most commonly observed forms in this classification system. ${ }^{4-8}$ The degenerative type is more prevalent in females in the older age groups, while in the isthmic type, this relationship is inverted, with young males being the main group affected. ${ }^{9,10}$

The Meyerding classification quantifies the anterior translation of the superior vertebral body. The calculation is based on the percentage of displacement of the damaged vertebra on a scale from I to $\mathrm{V}$.

The anterior displacement of the vertebral body, together with the posterior displacement of the posterior arc of the inferior vertebra, promote an increase in the anteroposterior diameter of the spinal canal, and in the most severe cases a "double canal" aspect may be encountered. ${ }^{2,11,12}$

Currently, the proper treatment of spondylolisthesis is controversial and depends on the degree of slippage and on the symptoms presented. In many publications, the presence of a neurological deficit is the most precise indication for surgical treatment, which involves the decompression of the affected nerve root. ${ }^{4}$

\section{MATERIALS AND METHODS}

Fifty-seven tomographs of patients diagnosed with the two most common types of spondylolisthesis, isthmic and degenerative, were referred by spine surgeons to an imaging study clinic for study and vertebral analysis. Three cases were excluding for lack of data. The study was approved by the Institutional Review Board as number CAA:13736413.1.0000.5138

Of these 54 patients, 37 (29 women and 8 men) had the degenerative form of the disease and 17 (7 women and 10 men had the spondylolytic form.

The vertebral canal and the foramens of the slipped vertebra and of the adjacent superior vertebra were measured. (Figures 1 and 2)

First, an exploratory analysis was conducted with the goal of characterizing the patient sample using the frequency distributions for the qualitative variables and descriptive measurements (average, standard deviation) for the quantitative variables.

Contingency tables were used to associate the type of listhesis variable (degenerative and spondylolisthesis) with the clinical variables of interest. Pearson's chi-squared test or Fisher's exact test were used to test the statistical significance of the association between these variables.

For the evaluation of the differences between the diameters of the damaged vertebra and the vertebra above it, we used the Wilcoxon non-parametric test, which is applied when there is a comparison of measurements of a continuous variable between two paired groups. This test was applied to the measurements of both groups.

The research data were processed using the PASW Statistics, version 18. In all the statistical tests performed, a 5\% significance level was used, whereby associations with values of $p$ less than 0.05 are considered to be statistically significant.

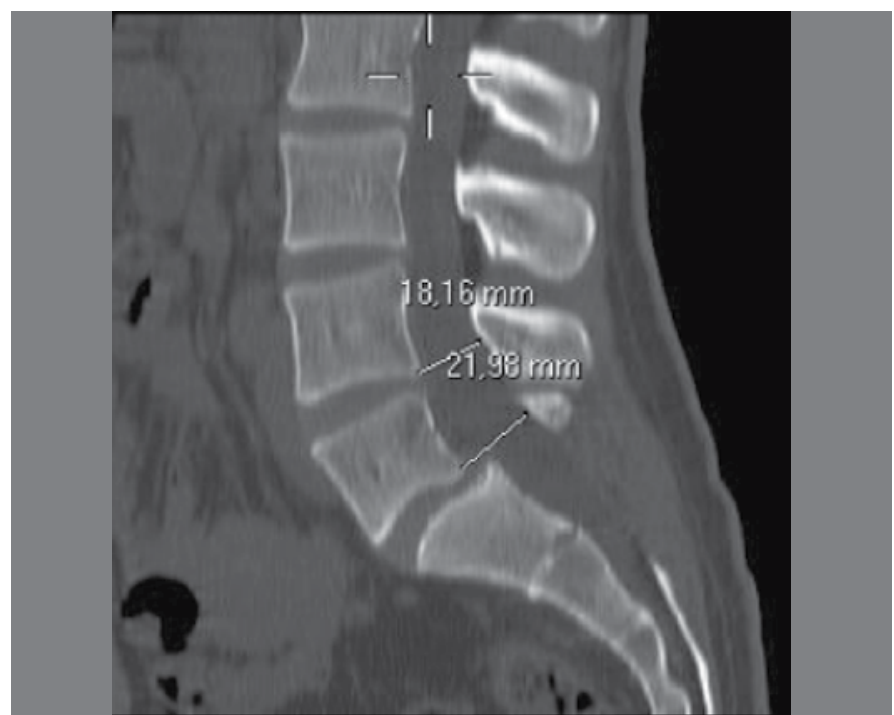

Figure 1. Example of the measurement of the vertebral canal.

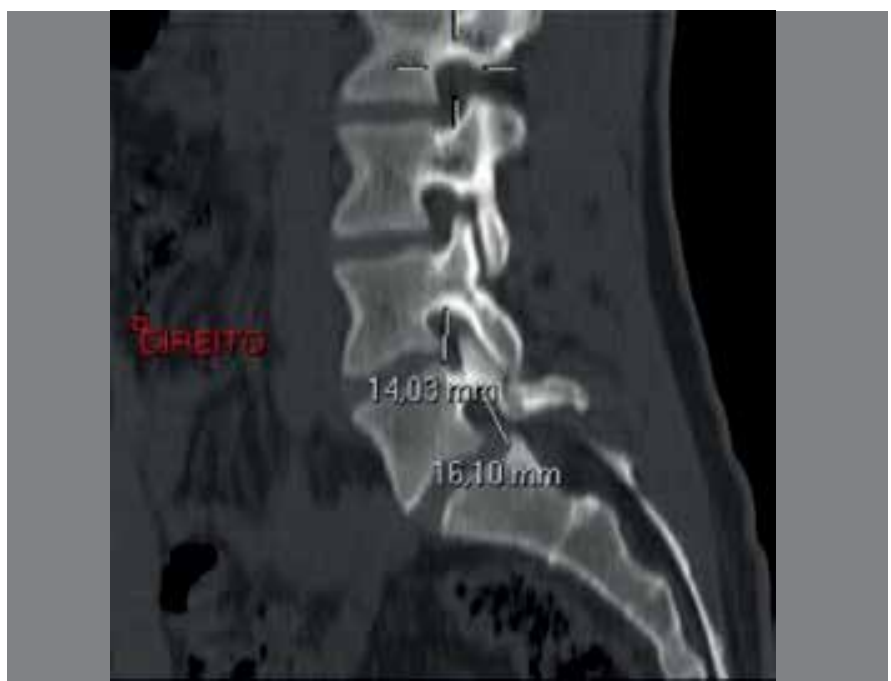

Figure 2. Example of the measurement of the vertebral foramen from the right.

\section{RESULTS}

Among the 37 patients with degenerative spondylolisthesis included in the study, 29 (78.4\%) were women and 8 (21.6\%) were men.

As regards the level of the vertebra, displacement of $L 4$ was prevalent in $67.6 \%$ of the patients in the degenerative group, while displacement at level L5 was observed in $29.7 \%$ of the sample.

It was also confirmed that all patients (100\%) in this group had discoarthrosis.

Facet and arthritic changes were observed in 34 (91.9\%) patients with degenerative spondylolisthesis.

Among the 17 patients with the spondylolytic type included in the study, 7 (41.2\%) were women and 10 (58.8\%) were men.

In terms of the vertebral level, L5 was most the most affected, at $82.4 \%$, while L4 was affected in $17.2 \%$ of the sample.

It was also confirmed that most of the patients (82.4\%) did not have discoarthrosis, but it was present in $17.6 \%$ of the patients.

Facet and arthritic changes were absent in all 17 patients.

The data obtained from the sample showed that $76.5 \%$ had slippage identified as grade 1 or grade 3 while $17.6 \%$ had grade 2 slippage.

No statistically significant correlation between the type of listhesis and the degree of the slippage was observed.

The ages of the degenerative group ranged from 45 to 94 years with an average of 66.3 years of age. (Table 1 ) 
The average diameter of the canal was $17.35 \mathrm{~mm}$ at the level of the damaged vertebra and $17.64 \mathrm{~mm}$ at the level of the superior vertebra.

The average diameter of the left foramen at the level of the damaged vertebra was $14.61 \mathrm{~mm}$. The average diameter of the right foramen at the level of the damaged vertebra was $15.00 \mathrm{~mm}$.

The average diameter of the left foramen at the level of the vertebra above the damaged vertebra was $16.82 \mathrm{~mm}$, and that of the right foramen was $16.51 \mathrm{~mm}$. (Table 2)

The ages of the spondylolytic group ranged from 10 to 64 years.

The average diameter of the canal at the level of the damaged vertebra was $23.25 \mathrm{~mm}$ and at the level of the superior vertebra was $18.66 \mathrm{~mm}$.

The average diameter of the left foramen at the level of the damaged vertebra was $11.98 \mathrm{~mm}$. The average diameter of the right foramen at the level of the damaged vertebra was $12.34 \mathrm{~mm}$.

The average diameter of the left foramen at the level of the vertebra above the damaged vertebra was $16.97 \mathrm{~mm}$, and that of the right foramen was $15.88 \mathrm{~mm}$. (Table 3)

Table 4 shows the results of the comparison of the diameters of the damaged vertebra and the superior vertebra by type of listhesis.

In the group of spondylolytic patients, the diameter of the canal of the damaged vertebra was greater than that of the superior vertebra.

We observed a mean left foramen diameter of $14.54 \mathrm{~mm}$ at the level of the damaged vertebra in the degenerative group, while that of the superior vertebra was $16.5 \mathrm{~mm}$. A comparison of these two instances yields an increase in diameter of approximately $13.5 \%$.

This increase is even more evident in the spondylolytic group when the left foramen of the damaged vertebra is compared to that of the superior vertebra, representing an increase in diameter of approximately $31.3 \%$.

In the degenerative group, the mean diameter of the right foramen was $15.16 \mathrm{~mm}$ for the damaged vertebra and $16.54 \mathrm{~mm}$ for

Table 1. Frequency distribution of the 37 degenerative-type patients and the 17 spondylolytic-type patients by clinical and demographic characteristics.

\begin{tabular}{|c|c|c|c|c|c|}
\hline \multirow{2}{*}{ Variables } & \multicolumn{2}{|c|}{ Degenerative } & \multicolumn{2}{|c|}{ Spondylolytic } & \multirow{2}{*}{ P-value } \\
\hline & $\mathbf{N}$ & $\%$ & $\mathbf{N}$ & $\%$ & \\
\hline \multicolumn{6}{|l|}{ Sex } \\
\hline Female & 29 & 78.4 & 7 & 41.2 & \multirow{2}{*}{0.012} \\
\hline Male & 8 & 21.6 & 10 & 58.8 & \\
\hline \multicolumn{6}{|c|}{ Degree of slippage } \\
\hline Grade 1 & 34 & 91.9 & 13 & 76.5 & \multirow{3}{*}{0.283} \\
\hline Grade 2 & 2 & 5.4 & 3 & 17.6 & \\
\hline Grade 3 & 1 & 2.7 & 1 & 5.9 & \\
\hline \multicolumn{6}{|l|}{ Vertebra } \\
\hline L3 & 1 & 2.7 & 0 & 0 & \multirow{3}{*}{0.001} \\
\hline L4 & 25 & 67.6 & 3 & 17.6 & \\
\hline L5 & 11 & 29.7 & 14 & 82.4 & \\
\hline \multicolumn{6}{|c|}{ Discoarthrosis } \\
\hline No & 0 & 0 & 14 & 82.4 & \multirow{2}{*}{0.000} \\
\hline Yes & 37 & 100 & 3 & 17.6 & \\
\hline \multicolumn{6}{|c|}{ Facet and arthritic changes } \\
\hline No & 3 & 8.1 & 17 & 100 & \multirow{2}{*}{0.000} \\
\hline Yes & 34 & 91.9 & 0 & 0 & \\
\hline Total & 37 & 100 & 17 & 100 & \\
\hline
\end{tabular}

Note: $p$-value: descriptive level of the chi-squared test the superior vertebra, representing an approximate increase of $9.1 \%$ compared to the damaged vertebra.

This increase is greater in the spondylolytic group in a comparison of the right foramens of the damaged and superior vertebrae, with an increase in the diameter of approximately $15.2 \%$

\section{DISCUSSION}

The increase in the anteroposterior diameter of the canal at the level of the defect can be seen as the result of both the anterior displacement of the vertebral body in relation to the posterior elements and the posterior displacement of the neural arc of the vertebrae above and below the damaged vertebra. ${ }^{2}$ Although there

Table 2. Descriptive statistics of the 37 degenerative-type patients by clinica and demographic characteristics.

\begin{tabular}{c|c|c|c|c|c|c|c}
\hline \multirow{2}{*}{ Variables } & \multicolumn{7}{|c}{ Descriptive measurements } \\
\cline { 2 - 8 } & Average & SD & Min & Max & P25 & Mean & P75 \\
\hline AGE & 66.35 & 9.43 & 45.00 & 94.00 & 60.50 & 68.00 & 71.00 \\
\hline SDDV & 17.35 & 1.64 & 14.06 & 20.93 & 16.01 & 17.15 & 18.83 \\
\hline SDSV & 17.64 & 1.86 & 13.90 & 22.52 & 16.10 & 17.57 & 18.79 \\
\hline DLFDV & 14.61 & 2.83 & 8.69 & 20.74 & 13.12 & 14.54 & 16.13 \\
\hline DLFSV & 16.82 & 2.57 & 12.63 & 23.09 & 14.62 & 16.50 & 19.08 \\
\hline DRFDV & 15.00 & 2.50 & 9.54 & 19.85 & 13.46 & 15.16 & 16.81 \\
\hline DRFSV & 16.51 & 2.03 & 12.04 & 20.05 & 15.44 & 16.54 & 18.20
\end{tabular}

Note: SDDV - sagittal diameter of the damaged vertebra; SDSV - sagittal diameter of the superior vertebra; DLFDV - diameter of the left foramen of the damaged vertebra; DLFSV - diameter of the left foramen of the superior vertebra; DRFDV - diameter of the left foramen of the damaged vertebra DRFSV - diameter of the right foramen of the superior vertebra

Table 3. Descriptive statistics of the 17 spondylolytic-type patients by clinical and demographic characteristics.

\begin{tabular}{c|c|c|c|c|c|c|c}
\hline \multirow{2}{*}{ Variables } & \multicolumn{7}{|c}{ Descriptive measurements } \\
\cline { 2 - 8 } & $\begin{array}{c}\text { Ave- } \\
\text { rage }\end{array}$ & SD & Min & Max & P25 & Mean & P75 \\
\hline AGE & 38.06 & 14.23 & 10.0 & 64.0 & 27.50 & 41.0 & 47.50 \\
\hline SDDV & 23.25 & 5.22 & 14.83 & 35.79 & 20.72 & 22.75 & 25.06 \\
\hline SDSV & 18.66 & 2.78 & 14.07 & 23.58 & 15.81 & 18.77 & 20.72 \\
\hline DLFDV & 11.98 & 3.62 & 5.69 & 18.21 & 9.56 & 12.39 & 14.72 \\
\hline DLFSV & 16.97 & 3.02 & 12.80 & 23.55 & 14.23 & 16.27 & 18.84 \\
\hline DRFDV & 12.34 & 3.83 & 4.37 & 16.91 & 9.68 & 13.21 & 15.53 \\
\hline DRFSV & 15.58 & 2.86 & 9.09 & 21.50 & 13.80 & 15.22 & 17.68 \\
\hline
\end{tabular}

Note: SDDV - sagittal diameter of the damaged vertebra; SDSV - sagittal diameter of the superio vertebra; DLFDV - diameter of the left foramen of the damaged vertebra; DLFSV - diameter of the left foramen of the superior vertebra; DRFDV - diameter of the left foramen of the damaged vertebra; DRFSV - diameter of the right foramen of the superior vertebra

Table 4. Evaluation of the values of the diameters of the damaged vertebra and the superior vertebra by type of listhesis.

\begin{tabular}{c|c|c|c|c|c}
\hline \multirow{2}{*}{$\begin{array}{c}\text { Clinical } \\
\text { Variables }\end{array}$} & Group & $\begin{array}{c}\text { Dama- } \\
\text { ged } \\
\text { Vertebra }\end{array}$ & $\begin{array}{l}\text { Superior } \\
\text { Vertebra }\end{array}$ & P-value & Conclusion \\
\hline $\begin{array}{c}\text { Diameter of } \\
\text { the Canal }\end{array}$ & Degenerative & 17.15 & 17.57 & 0.301 & SDDV $=$ SDSV \\
\cline { 2 - 4 } & Spondylolytic & 22.75 & 18.77 & $0.003^{* *}$ & SDDV $>$ SDSV \\
\hline $\begin{array}{c}\text { Diameter } \\
\text { of the Left } \\
\text { Foramen }\end{array}$ & Degenerative & 14.54 & 16.5 & $0.000^{* *}$ & DLFDV $<$ DLFSV \\
\cline { 2 - 4 } & Spondylolytic & 12.39 & 16.27 & $0.002^{* *}$ & DLFDV $<$ DLFSV \\
\hline $\begin{array}{c}\text { Diameter } \\
\text { of the Right } \\
\text { Foramen }\end{array}$ & Degenerative & 15.16 & 16.54 & $0.010^{\star *}$ & DRFDV $<$ DRFSV \\
\cline { 2 - 4 } & Spondylolytic & 13.21 & 15.22 & $0.025^{*}$ & DRFDV $<$ DRFSV \\
\hline
\end{tabular}

Note: - The probabilities of significance ( $p$-value) are in reference to the Wilcoxon test - The significant results were identified with asterisks according to the level of significance, namely: $\mathrm{p}$-value $<0.01^{\star *}$ ( $99 \%$ confidence level) and p-value < 0.05 * (95\% confidence level) Source: Study data 
is consensus in the literature around the increase in the diameter of the vertebral canal in spondylolytic spondylolisthesis, we did not find any quantitative evaluation of the degree of the increase, or the relationship between this increase to the degree of slippage, as defined by the Meyerding classification. ${ }^{6}$

In terms of any linkage between the type of listhesis and discoarthrosis in the patients, we observed that these variables are interdependent. This is supported by the fact that $100 \%$ of the degenerative group patients had discoarthrosis in contrast to $82.4 \%$ of the spondylolytic group patients who did not present discoarthrosis. (Table 1)

Regarding the type of listhesis and the vertebra affected, we observed a dependency between these variables and the $p$-value was less than 0.05 . This is due to the fact L4 was involved in $67.6 \%$ of the degenerative group whereas $82.4 \%$ of the spondylolytic group were affected in L5. (Table 1)

Facet changes were present only in the degenerative group.

The pertinent results from a comparison of the values of the diameters of the damaged vertebra and the superior vertebra showed that patients in both the degenerative and spondylolytic groups had smaller foraminal diameters in the vertebra at the damaged level. There was no statistical difference between the diameter of the vertebral canal at the damaged level and the vertebral canal at the superior level. (Table 4) (9-11 $^{-1}$

Considering that this work prioritized the study of bone measurements, an opportunity is open for new studies that include the "soft tissues" and allow higher accuracy in measuring the real variation in the sagittal and transverse diameters of the vertebral canal.

\section{CONCLUSION}

We concluded that there was a statistically significant increase in the diameter of the canal in the sagittal plane in the spondylolytic group that was not observed in the group with degenerative spondylolysis. We also observed a reduction in the foramens at the damaged level in both groups.

All the authors declare that there are no potential conflicts of interest regarding this article.

All authors declare no potential conflict of interest concerning this article.

CONTRIBUTIONS OF THE AUTHORS: Each author made a significant individual contribution to the development of the manuscript. TABO was the author. (ou "one of the authors" caso seja mais de um autor) EBG was the main author, the pioneer of the work, and the supervisor. HBD conducted the literature review. EBGJ, LFG and RGG carried out the evaluation of patients' records and the data collection. LAS and GAVB conducted the literature review. JCTM and RNR analyzed the images.

\section{REFERENCES}

1. Tebet MA, Pasqualini W, Carvalho MP, Fusão AF, Segura EL. Surgical treatment of degenerative and isthmic lumbar spine spondylolisthesis: clinical and radiographic evaluation. Coluna/Columna. 2006;5(2):109-16.

2. Zoner, CS; Amaral, DT; Natour, J; Fernandes, AR. Contribution of the Imaging Methods in the Evaluation of Spondylolysis. Rev Bras Reumatol. 2006:46(4):287-91.

3. Wiltse LL, Newman PH, Macnab I. Classification of spondylolisis and spondylolisthesis. Clin Orthop Relat Res. 1976:(117):23-9.

4. Kornblum MB, Fischgrund JS, Herkowitz HN, Abraham DA, Berkower DL, Ditkoff JS Degenerative lumbar spondylolisthesis with spinal stenosis: a prospective long-term study comparing fusion and pseudarthrosis. Spine (Phila Pa 1976). 2004;29(7):726-33.

5. Canale ST, Beaty JH. Campbell's operative orthopaedics. 11th. ed. Philadelphia: Elsevier; 2007

6. Meyerding HW. Spondylolisthesis. Surg Gynecol Obstet. 1932;54:371-7.
7. Wiltse LL, Rothman SLG. Spondylolisthesis: classification, diagnosis and natural history. Semin Spine Surg. 1989;1:78-94.

8. Wiltse LL, Winter RB. Terminology and measurement of spondylolisthesis. J Bone Joint Surg Am. 1983:65(6):768-72.

9. Leone A, Guglielmi G, Cassar-Pullicino VN, Bonomo L. Lumbar intervertebral instability: a review. Radiology. 2007;245(1):62-77.

10. Sengupta DK, Herkowitz HN. Degenerative spondylolisthesis: review of current trends and controversies. Spine (Phila Pa 1976). 2005;30(Suppl 6):S71-81.

11. Fredrickson BE, Baker D, McHolick WJ, Yuan HA, Lubicky JP. The natural history of spondylolysis and spondylolisthesis. J Bone Joint Surg Am. 1984;66(5):699-707.

12. Kwon BK, Hilibrand AS, Malloy K, Savas PE, Silva MT, Albert TJ, et al. A critical analysis of the literature regarding surgical approach and outcome for adult low-grade isthmic spondylolisthesis. J Spinal Disord Tech. 2005;18 (Suppl):S30-40. 